\title{
Penerapan Sistem Agribisnis Peternakan Kambing Jawa Randu dalam Kerangka Pengembangan Wilayah Kecamatan Karangpucung, Kabupaten Cilacap
}

\author{
Dewi Norytyas Prihatiningrum ${ }^{1}$ \\ Ditjen Pengembangan Perwilayahan Industri \\ Kementerian Perindustrian, Jakarta Selatan, Indonesia
}

\begin{abstract}
Abstrak: Kecamatan Karangpucung merupakan sentra peternakan kambing Jawa Randu yang dikembangkan oleh sebagian besar masyarakat setempat. Jenis kambing Jawa Randu merupakan hasil persilangan kambing Jawa dengan kambing Etawa, yang disebut kambing Jawa Randu. Hasil peternakan kambing Jawa Randu memiliki peminat tinggi, bukan hanya dari masyarakat lokal saja namun juga peminat dari luar daerah bahkan luar provinsi. Konsumen Kambing Jawa Randu berasal dari Banyumas, Banjarnegara, Purworejo, Kebumen, Jawa Barat dan DKI, dan sekitarnya. Namun demikian, pengembangannya selama ini hanya dilakukan dengan cara tradisional yang turun temurun bahkan sebagian masih berifat subsisten atau hanya untuk mencukupi kebutuhan sendiri, dan belum berorientasi belum berorientasi pada sistem agribisnis secara keseluruhan karena masih mengalami kendala dalam melakukan subsistem hilir. Tujuan penelitian ini adalah untuk merumuskan penerapan sistem agribisnis peternakan kambing Jawa Randu dalam kerangka pengembangan wilayah di Kecamatan Karangpucung. Sasaran studi ini meliputi analisis aktivitas peternakan kambing Jawa Randu, analisis keterkaitan antar wilayah, analisis keterkaitan ke belakang dan ke depan, dan analisis penerapan sistem agribisnis peternakan kambing dalam kerangka pengembangan wilayah Kecamatan Karangpucung. Teknik analisis yang digunakan meliputi analisis kuantitatif dan analisis kualitatif. Analisis kuantitatif digunakan dengan menggunakan metode kalkulasi yang menghitung usaha tani serta menghitung kelayakan financial industri pengolahan kulit. Analisis kualitatif digunakan dengan metode deskriptif kualitatif serta dengan menggunakan skema yang menggambarkan kondisi eksisting aktivitas peternakan kambing Jawa Randu. Output yang dihasilkan dari penelitian ini adalah diketahuinya level penerapan sistem agribisnis peternakan kambing Jawa Randu yang baru sampai pada kegiatan hulu, budidaya, dan penunjang, sedangkan pada kegiatan hilir baru berupa pengolahan pupuk. Secara keseluruhan dapat disimpulkan bahwa jika sistem agribisnis diterapkan pada peternakan kambing Jawa Randu, maka Kecamatan Karangpucung akan bisa berkembang terkait dengan peningkatan pendapatan, penyerapan tenaga kerja, penyediaan bahan pangan, dan pengembangan fisik Kecamatan Karangpucung.
\end{abstract}

Kata kunci: agribisnis, pengembangan wilayah, peternakan

Abstract: Karangpucung sub-district is centers of Jawa Randu Goats ranch developed by most of the local community. Thet kind of Jawa Randu goats is the result of a cross Jawa goats with Ettawa. The result of Jawa Randu goats ranch having high devotees, not only from local people but also from outside area even outside the province. Consumers of Jawa

\footnotetext{
1 Korespondensi Penulis: Ditjen Pengembangan Perwilayahan Perindustrian, Kementerian Perindustrian, Jakarta Selatan Email: dewinory@gmail.com
} 
Randu goats derived from Banyumas, Banjarnegara, Purworejo, Kebumen, West Java and city and the surrounding area. However, development costs during this is only done in a traditional manner that hereditary and some even still are subsistence or only to even support their own, and have not oriented business. Of some of the problems, can be made the formulation of the problem, namely that the activities of the development of peternakan goatie java randu not oriented in a system of agribusiness overall because it still had difficulty in doing downstream off farm agribusiness subsistem. The purpose of this research is to formulate the implementation of the Jawa Randu goats ranch agribusiness system within the framework of the Karangpucung sub-district development. The target of this study includes: the activity of Jawa Randu goats ranch analysis, rural-urban linkage analysis, backward and forward linkage analysis, and analysis of the application of the Jawa Randu goats ranch agribusiness system within the framework of the Karangpucung sub- district development. Analysis techniques used covering quantitative analysis and qualitative analysis. Quantitative analysis used by using a calculation method that calculates farming and also feasibility analysis of financial as well as calculate the leather processing industry. Whereas qualitative analysis used with a method of descriptive qualitative as well as by the use of a scheme who described the existing conditions of Jawa Randu goats ranch activities. The result from this research is the application level system from the Jawa Randu goats ranch include the upstream activities, cultivation, and supporting institution activity. Calculation of usahatani is done, the cultivation of goat husbandry is carried out without variation of downstream off farm agribusiness only income for breeders of $R p$ 676.875,00 per month, of which only cover daily needs. Whereas the financial feasibility analysis based on variations in the form of lower processing goat leathers be crackers, milk be whole milk, and slaughterhouse animals generated that revenue obtained each breeder is $R p \quad 3.525 .565$ Usd,19, $R p$ 6.623.342, 10 and $R p$ 88.692.774,00 per month. If applied agribusiness system in Jawa Randu goat farming will also absorb labor as much as 7,061 people. Analysis of the application of the system of agri-well known that there will be changes to the structure and pattern space Sub Karangpucung and surrounding area, is due to be growing into the SWP IV agropolitan, in accordance with the direction of RTRW of Cilacap Regency in the year 20112031. From this it was concluded that if the system is applied to the Jawa Randu goats ranch then will develop Karangpucung sub-district associated with increased income, labor absorption, the provision of foodstuffs, and physical development of Karangpucung subdistrict.

Keywords: agribusiness, ranch, regional development

\section{Pendahuluan}

Pengembangan wilayah pedesaan merupakan strategi untuk memeratakan pembangunan dalam rangka mengurangi disparitas pembangunan perkotaan dengan pedesaan. Antara pembangunan pertanian dan pembangunan pedesaan terdapat hubungan yang sangat erat. Pembangunan pedesaan tidak akan dapat berhasil dengan baik jika mengabaikan pembangunan pertanian, dan sebaliknya pembangunan pertanian juga sulit melepaskan diri dari perdesaan karena di antara faktor penentu keberhasilannya yaitu petani dan lahan berada di wilayah pedesaan. Salah satu strategi untuk mengembangkan wilayah pedesaan adalah dengan mengembangkan potensi/komoditi unggulan wilayahnya. Agribisnis merupakan sistem untuk mengembangkan potensi unggulan tersebut, yang merupakan kesatuan kegiatan usaha yang meliputi salah satu atau keseluruhan dari mata rantai produksi, pengolahan hasil dan pemasaran yang ada hubungannya dengan pertanian dalam arti luas (Arsyad, dkk. 1985). Menurut Soekartawi (2003), agribisnis merupakan suatu kegiatan yang salah satu atau keseluruhan kegiatan yang meliputi mata rantai produksi, pengolahan hasil dan pemasaran yang ada hubungannya dengan pertanian dalam arti luas. Pertanian dalam arti luas adalah kegiatan usaha yang menunjang kegiatan pertanian dan 
kegiatan usaha yang ditunjang oleh kegiatan pertanian. Agribisnis peternakan digambarkan sebagai sebuah sistem yang terdiri atas lima subsistem yaitu subsistem pembuatan, pengadaan, penyaluran berbagai sarana produksi pertanian (farm supplier), subsistem kegiatan produksi yang menghasilkan berbagai produk ternak, serta subsistem pengumpulan, pengolahan, penyimpanan dan penyaluran berbagai produk pertanian yang dihasilkan usaha ternak atau hasil olahannya ke konsumen (Firdaus, 2008). Dari pengertian tersebut, maka peternakan dengan sistem agribisnis sangat konsisten diterapkan di masyarakat pedesaan karena dapat menyentuh masyarakat yang bermodal kecil dan dapat mengembangkan wilayah kawasan pedesaan.

Kecamatan Karangpucung yang terletak di bagian barat Kabupaten Cilacap merupakan sentra peternakan kambing Jawa Randu yang sudah berlangsung sejak lama, karena merupakan bagian dari budaya masyarakat pedesaan setempat. Jumlah hewan ternak kambing di Kecamatan Karangpucung lebih banyak dibandingkan dengan jumlah hewan lain kecuali ayam, seperti sapi, kerbau, domba, itik, dan lain-lain. Pada tahun 2010, tercatat jumlah kambing yang diternak oleh masyarakat sebanyak 18.335 ekor, dengan jumlah peternak sebanyak 5.126 peternak. Angka tersebut merupakan angka yang besar bagi kecamatan yang bisa dikatakan terpencil, dan dapat dikatakan sebagian besar penduduknya beternak hewan kambing, karena dari $21.585 \mathrm{KK}$, terdapat 5.126 peternak (Monografi Kecamatan Karangpucung, 2010).

Kambing khas Karangpucung merupakan hasil persilangan antara kambing Kacang (Jawa) dengan kambing ras Etawa. Hasil persilangan tersebut menghasikan spesies baru yang kemudian disebut sebagai kambing Jawa Randu, yang mempunyai keunikan tersendiri karena mempunyai ciri fisik yang berbeda dari kambing PE maupun dengan kambing Kacang (lokal). Disamping itu kualitas dan jenis pakan berupa rambanan ('browse') menjadi keunggulan bagi aktivitas budidaya karena menghasilkan kualitas fisik dan daging yang lebih bagus dibanding kambing yang diternakkan di daerah lain menjadi keunikan tersendiri. Keunikan tersebut yang menyebabkan kambing Jawa Randu memiliki pangsa pasar yang sudah cukup luas hingga ke Kabupaten Banyumas, Banjarnegara, Purworejo, Kebumen, Provinsi Jawa Barat dan DKI (BP2KP Kecamatan Karangpucung, 2011). Luasnya pangsa pasar tersebut didukung dengan keberadaan pasar kambing yang sangat besar dan terkenal yang terletak di Pasar Tradisional Karangpucung dan letak Kecamatan Karangpucung yang strategis dan dilalui jalan negara yang menghubungkan Jawa Tengah dengan Jawa Barat (Marsono, 2011).

Potensi peternakan kambing Jawa Randu seharusnya bisa dikembangkan menjadi peternakan kambing Jawa Randu dengan sistem agribisnis untuk memperoleh peningkatan nilai ekonomi, tingkat efisiensi dan produktivitas tinggi. Peran adanya peternakan kambing Jawa Randu ini juga mendorong pengembangan wilayah Kecamatan Karangpucung sendiri. Peternakan kambing Jawa Randu menjadi sumber penghasilan bagi sebagian besar masyarakat, karena dengan beternak kambing, masyarakat dapat bekerja sekaligus membuka lapangan pekerjaan baru dan dapat mengembangkan usaha lain selain beternak, seperti usaha warung sate gulai, dan usaha makanan berbahan kambing (Darsim, 2011).

Yang menjadi permasalahan dalam pengembangan peternakan kambing tersebut adalah Kecamatan Karangpucung masih hanya sebagai sentra produksi kambing dan pemasaran, tanpa memanfaatkan hasil produksi seperti susu, daging dan kulit untuk mendapatkan nilai tambah. Selama ini, kegiatan peternak sebagian besar hanya meliputi subsistem hulu, primer tani, dan penunjang serta sedikit pada kegiatan hilir. Menurut Kepala BP2KP Kecamatan Karangpucung (2012), saat ini baru beberapa desa yang telah memanfaatkan kotoran ternak kambing sebagai pupuk kompos yang dimanfaatkan untuk memupuk lahan sawah ataupun dijual. Dari penjelasan tersebut dapat disimpulkan bahwa kegiatan pengembangan peternakan kambing Jawa Randu belum sepenuhnya berorientasi pada sistem agribisnis. Dengan sistem peternakan yang selama ini dilakukan oleh peternak, 
peternak hanya mampu menghasilkan output berupa kambing dan daging kambing saja, sehingga peternak tidak mendapatkan nilai tambah dari usaha peternakan. Dari permasalahan yang dijelaskan di atas, maka diperlukan suatu kajian mengenai bagaimana penerapan sistem agribisnis peternakan kambing Jawa Randu yang sekaligus mengkaji bagaimana perannya dalam pengembangan wilayah pedesaan di Kecamatan Karangpucung, yang dikaitkan dengan peningkatan pendapatan peternak, penyerapan tenaga kerja, ketersediaan pangan, dan pengembangan fisik Kecamatan Karangpucung.

Penelitian ini bertujuan untuk mengetahui bagaimana sistem agribisnis peternakan kambing Jawa Randu dalam mendukung pengembangan wilayah di Kecamatan Karangpucung, Kabupaten Cilacap.

\section{Kajian Literatur}

\section{Pengembangan Wilayah}

Terdapat 2 paradigma pengembangan wilayah yaitu development from above dan development from below.

- Development From Above

Berorientasi pada kota besar, berasal dari teori neo klasik (capital factor). Jenis- jenis teori terdiri atas:

1) Intermediate city

2) Sistem kota-kota

3) Backwash effect (penyedotan sumber daya dari desa ke kota)

4) Growth pole, didasari oleh adanya unbalance growth

Aktivitas yang dikembangkan adalah ekonomi, sosial dan budaya, dan lain sebagainya. Akan tetapi tidak mudah memindahkan aktivitas tersebut, oleh karena itu dapat melalui insentif dan disinsentif, kebijakan yang tepat serta rencana yang komprehensif. Ide dasar intermediate city adalah menciptakan kota terpadu dan menciptakan keterkaitan antar kota sesuai dengan fungsinya masing-masing (tercipta sistem koleksi dan distrribusi) menghasilkan sistem perkotaan yang mencakup sistem transportasi, termasuk di dalamnya jaringan jalan regional.

Ciri utama growth pole adalah:

- Konsep leading industries tercipta linkage yang sangat kuat dan efektivitas tinggi.

- Polarisasi yaitu terciptanya aglomerasi dan memperkecil suatu sektor yang memiliki keterkaitan dengan banyak sektor untuk mengefisiensikan prasarana.

- Speed effect yaitu terjadinya perkembangan ke daerah pinggiran karena polarisasi tidak efisien lagi.

\section{- Development From Below}

Proses internalisasi potensi lokal wilayah merupakan awal bagaimana suatu wilayah dapat berkembang. Menurut perspektif teori ini, terdapat berbagai strategi pendekatan pengembangan wilayah yaitu pengembangan teritorial, funsgional, dan pendekatan agropolitan. Secara umum pendekatan-pendekatan tersebut memfokuskan pada upaya melepaskan diri dari ketergantungan terhadap wilayah pusat.

- Agropolitan dan selective spatial closure sebagai konsep pengembangan wilayah

Agropolitan district growth merupakan suatu kebijakan tertutup dalam strategi pengembangan wilayah. Pada dasarnya konsep pengembangan wilayah agropolitan (Friedmann dan Douglas,1976) berawal dari tingkat perkembangan yang berbeda dan keterkaitan tidak simetris yang mengarah pada terjadinya leakage sehingga menyebabkan terjadinya distorsi antara rural dan urban. Pengembangan rural yang 
berkelanjutan dengan basis pemenuhan kebutuhan dasar merupakan salah satu saran dari pendekatan agropolitan.

Yang dimaksud dengan agropolitan adalah kota pertanian yang tumbuh dan berkembang karena berjalannya sistem dan usaha agribisnis sera mampu melayani, mendorong, dan menarik, menghela kegiatan pembangunan pertanian (agribisnis) di wilayah sekitarnya. Kota agropolitan berada dalam kawasan sentra produksi pertanian. Kota pertanian dapat merupakan kota menengah, kota kecil, kota kecamatan, kota perdesaan atau kota nagaru berfungsi sebagai pusat pertumbuhan ekonomi yang mendorong pertumbuhan pembangunan perdesaan dan desa-desa hinterland di wilayah sekitarnya.

\section{Sistem Agribisnis}

Agribisnis seringkali dirancukan dengan pertanian, baik dalam persepsi maupun aktualitasnya. Secara gamblang, agribisnis didefinisikan sebagai: "the sum total of all operations involved in the manufacture and distribution of farm supplies; production operations on the farm, processing and distribution of farm commodities and items made from them" (David dan Goldberg, 1957). Agribisnis mencakup 4 (empat) hal berikut (Fatah, 2006):

- Pertama, subsektor agribisnis hulu (upstream agribussines) yakni kegiatan ekonomi yang menghasilkan sarana produksi, pertama (the manufactoure and distribution of farm supptress) industri agrohilir (industri pupuk, industri pupuk, pestisisda, industri obat-obatan hewan) dan industri agro-otomotif (industri mesin pertanian, industri peralatan pertanian, industri mesin, dan peralatan pengolahan hasil pertanian).

- Kedua, subsektor agribisnis primer (on farm agribusiness) atau disebut pertanian dalam arti luas (production operation on the farm), yaitu pertanian tanaman pangan, holtikultura, tanaman obat-obatan, perkebunan, peternakan, perikanan laut dan air tawar serta kehutanan.

- Ketiga, subsektor agribisnis hilir (down stream agribusiness) yaitu kegiatan industri yang mengolah komoditas pertanian menjadi produk-produk olahan baik produk antara (intermediate product) maupun produk akhir (final product). Dengan kata lain subsektor agrbisnis meliputi pergudangan (storage), pengolahan (proccessing), dan distribusi komoditas pertanian (distribution of farm commodities), serta berbagai produk yang dihasilkan dari komoditas pertanian (items made from them).

- Keempat, subsektor jasa penunjang (supporting institutions) yakni kegiatan yang menghasilkan dan menyediakan jasa yang dibutuhkan seperti pemasaran, transportasi, penelitian dan pengembangan, kebijakan pemerintah, penyuluhan, konsultasi dan lainlain.

Menurut Siagian (2003:1-2), agribisnis mencakup industri-industri yang bekaitan antara industri yang mendukung dari sisi hulu ke hilir. Sehingga dapat diartikan jika agribisnis bisa menimbulkan kegiatan ke belakang (backward) yang ditimbulkan dari adanya aktivitas hulu dan bisa menimbulkan kegiatan ke depan (forward) yang diakibatkan dari adanya aktivitas hilir. Masing-masing kegiatan ini bertujuan untuk memperoleh keuntungan.

\section{Sistem Agribisnis Ternak Domba}

Menurut Saragih (2000), kegiatan agribisnis ternak domba telah lama berkembang mengikuti perkembangan perekonomian nasional. Hanya saja, perkembangan agribisnis ternak domba yang ada masih terpisah-pisah (belum terkoordinasi dalam suatu sistem), sehingga perkembangannya tidak secepat yang diharapkan dan pembagian manfaat yang 
ditimbulkannya belum proporsional. Dalam hal ini pelaku agribisnis yang berada pada bagian hilir (pedagang, pengusaha kulit) menikmati manfaat yang relatif besar, sementara para peternak hanya menikmati manfaat yang relatif kecil.

Suatu sistem agribisnis ternak domba dapat dibagi atas 4 (empat) subsistem, yaitu: (1) subsistem agribisnis hulu (upstream off-farm agribusiness), yaitu kegiatan ekonomi (produksi, perdagangan) yang menghasilkan sapronak seperti pembibitan domba, usaha/industri pakan, industri obat-obatan, industri inseminasi buatan, dan lain- lain, beserta kegiatan perdagangannya; (2) subsistem agribisnis budidaya ternak domba (onfarm agribusiness), yaitu kegiatan ekonomi yang selama ini disebut sebagai usaha ternak domba/kambing; (3) subsistem agribisnis hilir (downstream off-farm agribusiness), yaitu kegiatan ekonomi yang mengolah dan memperdagangkan hasil usaha ternak domba. Dalam subsistem ini termasuk industri pemotongan ternak domba, industri pengalengan daging domba, industri pengawetan kulit mentah domba, industri penyamakan kulit, industri sepatu dan alas kaki, industri barang-barang kulit beserta kegiatan perdagangan, baik domestik maupun ekspor; (4) subsistem jasa penunjang (supporting institution), yaitu kegiatan yang menyediakan jasa bagi agribisnis ternak domba seperti perbankan, asuransi, transportasi, penyuluhan, puskesnak, holding ground, kebijakan pemerintah (Dinas Peternakan), lembaga pendidikan dan penelitian, dan lain-lain.

\section{Metodologi Penelitian}

\section{Pendekatan dan Metode Penelitian}

Pendekatan penelitian berlandaskan paradigma positivistik dan rasionalistik, yang menggunakan teori sekaligus penelitian dan jurnal untuk membandingkan kondisi factual dengan konseptual. Metode yang digunakan dalam penelitian ini yaitu mixed methods approach dengan strategi sekuensial eksplanatori dimana didahulukan metode kuantitaif baru kemudian dilakukan metode kualitatif.

a. Metode Kuantitatif

Metode kuantitaif digunakan pada tahap pengumpulan data dengan menggunakan kuesioner yang disebarkan pada peternak. Pendekatan ini digunakan dalam menghitung prosentase jawaban peternak yang paling banyak dipilih, sehingga menjadi perwakilan dari keseluruhan sasaran kuesioner. Setelah dilakukan pengumpulan data tersebut, kemudian dilanjutkan dengan analisis pendapatan peternak dari hasil beternak kambing dengan penghitungan usaha tani. Selanjutnya adalah penghitungan peningkatan pendapatan dalam kerangka pengembangan wilayah dengan penghitungan analisis kelayakan usaha pengolahan hilir dari kambing.

b. Metode Kualitatif

Metode kualitatif juga digunakan dalam pengumpulan data dengan cara wawancara mendalam (depth interview) untuk mengetahui bagaimana karakteristik aktivitas peternakan kambing Jawa Randu. Pendekatan ini dalam tahap analisis dilakukan dengan teknik deskriptif untuk menggambarkan fenomena faktual yang ada di lapangan, kemudian generalisasi diambil dari perbandingan antara konsep dari teori (kontekstual) yang ada dengan kondisi faktual yang ada di lapangan.

\section{Penentuan dan Teknik Sampling}

Karena jumlah populasi sudah diketahui dengan pasti, maka teknik yang digunakan dalam mengambil sampel adalah simple random sampling, yaitu sebuah sampel yang diambil sedemikian rupa sehingga setiap unit penelitian atau satuan elementer dari populasi mempunyai kesempatan yang sama untuk dipilih sebagai sampel. Penggunaan teknik simple random sampling ini didasarkan pada populasi yang bersifat homogen karena 
seluruh populasi adalah peternak kambing, sehingga seluruh populasi mempunyai peluang yang sama untuk menjadi sampel.

Setelah diketahui jumlah sampel berdasarkan perhitungan simple random sampling, selanjutnya ditentukan jumlah sampel setiap desa dengan menggunakan teknik proportional sampling, dimana jumlah sampel dan responden yang akan diambil 14 desa dilakukan secara proporsional sesuai dengan jumlah populasi peternak di masingmasing desa tersebut. Teknik pengambilan sampel ini dipakai dengan tujuan untuk lebih memenuhi keterwakilan sampel yang diambil terhadap populasi.

\section{Analisis Data}

Analisis yang digunakan dalam penelitian ini adalah metode gabungan antara kuantitatif dan kualitatif.

a. Analisis Kuantitatif

Analisis kuantitatif digunakan pada variabel usaha tani yang telah dirumuskan sebelumnya berdasarkan jumlah kambing yang dimiliki peternak. Teknik kuantitatif yang digunakan berupa kalkulasi deskriptif pada analisis usaha tani, analisis kelayakan usaha hilir, dan analisis scoring dengan menggunakan distribusi frekuensi.

b. Analisis Kualitatif

Teknik analisis dalam penelitian ini menggunakan metode analisis deskriptif, yang berfungsi mendeskripsikan fenomena yang berkaitan dengan permasalahan yang dikaji. Teknik ini digunakan untuk menginterpretasikan data yang diperoleh dari jawaban responden atas wawancara yang dilakukan. Teknik kualitatif digunakan pada analisis aktivitas peternakan kambing Jawa Randu, analsis keterkaitan antar wilayah, dan analisis backward dan forward linkage.

\section{Temuan Studi}

\section{Analisis Aktivitas Peternakan Kambing Jawa Randu di Kecamatan Karangpucung}

Dari seluruh analisis aktivitas peternakan kambing Jawa Randu yang dikaitkan dengan sistem agribisnis, dapat disimpulkan mengenai penerapan sistem agribsisnis dalam dari aktivitas hulu, kegiatan budidaya , hilir dan penunjang dengan skema pada Gambar 1.

\section{Analisis Usaha Tani Peternakan Kambing Jawa Randu}

Dari Gambar 1 terlihat bahwa aktivitas peternakan kambing Jawa Randu belum meningkatkan keunggulan kompetitif dari produk mentah yaitu belum dilakukan variasi di kegiatan hilir. Peternak hanya sebatas memperdagangkan kambing mentah dan mengolah kotorannya saja. Dengan kegiatan yang demikian, peternak hanya memperoleh pendapatan dari menjual kambing saja, tanpa adanya peningkatan nilai tambah (value added) seperti pengolahan kulit, susu, dan dagingnya. 


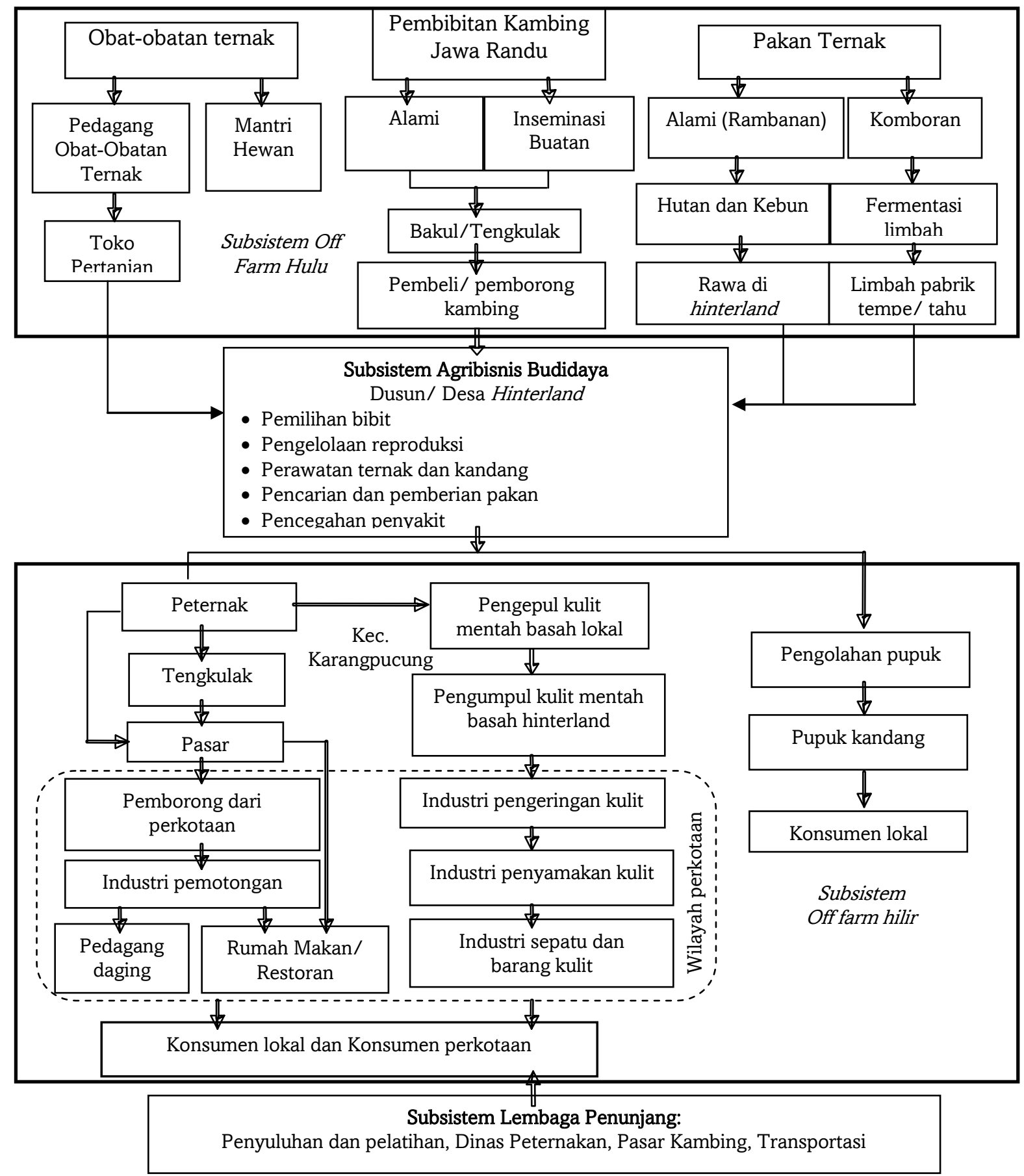

\section{Gambar 1. Penerapan Sistem Agribisnis Peternakan Kambing Jawa Randu Eksisting di Kecamatan Karangpucung}

Berikut adalah analisis usaha ternak kambing Jawa Randu yang didasarkan pada contoh analisis usaha ternak kambing www.deptan.go.id. Penghitungan didasarkan pada rata-rata peternak yang memiliki kambing 10 ekor, dengan 2 ekor jantan, dan 8 ekor betina. Hal tersebut dikarenakan berdasarkan hasil kuesioner, didapatkan rata-rata 
peternak memiliki kambing antara 5-10 ekor. Berikut adalah hasil perhitungan usaha tani peternakan kambing Jawa Randu:

Pendapatan Peternak:

$\begin{aligned} \text { Pd } & =\text { TR }- \text { TC } \\ & =\text { Rp 18.122.500 }- \text { Rp 10.000.000,- } \\ & =\text { Rp 8.122.500,- per tahun } \\ \text { Pendapatan Peternak } & =\text { Rp 676.875,- per bulan }\end{aligned}$

Pendapatan tersebut hanya dihasilkan dari penjualan kambing mentah saja, namun jika dilakukan variasi kegiatan hilir dikembangkan dari produk turunan dari kambing menjadi produk yang sifatnya intermediate, seperti: Kulit diolah menjadi kerupuk rambak, susu diolah menjadi susu cair murni (kambing perah), daging kambing potong, dengan usaha rumah potong hewan (RPH), maka pendapatan peternak adalah:

- Analisis Kelayakan Usaha Kerupuk Rambak dari Kulit Kambing

$$
\begin{aligned}
& \text { Jumlah Pendapatan } \quad=(30.054 .440,00+51.370 .606,00+47.916 .700,00+ \\
& 39.885 .383,50) / 4 \text { tahun } \\
& =\operatorname{Rp} 42.306 .782,25 / \text { tahun } \\
& =\text { Rp 3.525.565,19 per bulan }
\end{aligned}
$$

- Analisis Kelayakan Usaha Susu Murni Kambing Jawa Randu

$$
\begin{aligned}
& \text { Jumlah Pendapatan } \quad=(61.810 .902,00+63.307 .492,00+69.993 .970,00+ \\
& 122.808 .056,00) / 4 \\
& =\operatorname{Rp} 79.480 .105 / \text { tahun } \\
& =\text { Rp 6.623,342,10 per bulan }
\end{aligned}
$$

- Analisis Kelayakan Usaha Rumah Potong Hewan

$$
\begin{aligned}
\text { Jumlah Pendapatan }= & 1.098 .820 .620+1.169 .273 .860+1.057 .090 .700+ \\
& 932.067 .980 / 4 \\
= & 1.064 .313 .290 / \text { tahun } \\
= & \text { Rp 88.692.774,17 per bulan }
\end{aligned}
$$

Dari hasil perhitungan ke tiga kegiatan hilir berupa usaha kerupuk rambak, usaha pengolahan susu murni, dan usaha rumah potong hewan membuktikan bahwa terdapat peningkatan pendapatan yang akan didapatkan oleh peternak maupun masyarakat apabila melakukan variasi kegiatan hilir tersebut.

\section{Rural-Urban Linkage}

Dominasi oleh kegiatan pertanian dan atau agribisnis dalam suatu kesisteman yang utuh dan terintegrasi merupakan ciri-ciri kawasan agrpolitan. Kecamatan Karangpucung merupakan satu wilayah yang didominasi oleh kegiatan pertanian yang memiliki sektor unggulan belum berkembang dan belum didukung oleh sektor hilir, namun berpotensi dikembangkan menjadi kawasan agropolitan. Aktivitas peternakan kambing Jawa Randu dengan sistem agribisnis merupakan satu komponen yang mampu mendorong pembentukan Karangpucung menjadi kawasan agropolitan. Hubungan antar wilayah dalam aktivitas agribisnis peternakan kambing Jawa Randu ditimbulkan oleh kegiatan distribusi antar daerah yang pada akhirnya berpengaruh terhadap perkembangan wilayah Kecamatan Karangpucung. Kecamatan Karangpucung dengan wilayah sekitarnya sama-sama saling membutuhkan dalam kegiatan peternakan ini. Kecamatan Karangpucung membutuhkan demand dari wilayah di luarnya agar hasil budidaya kambing dapat terdistribusi dan mendatangkan pendapatan bagi peternak. Begitu juga dengan wilayah perkotaan yang 
membutuhkan supply berupa hewan kambing dari Karangpucung agar permintaan pasar akan daging dan barang jadi bisa terpenuhi.

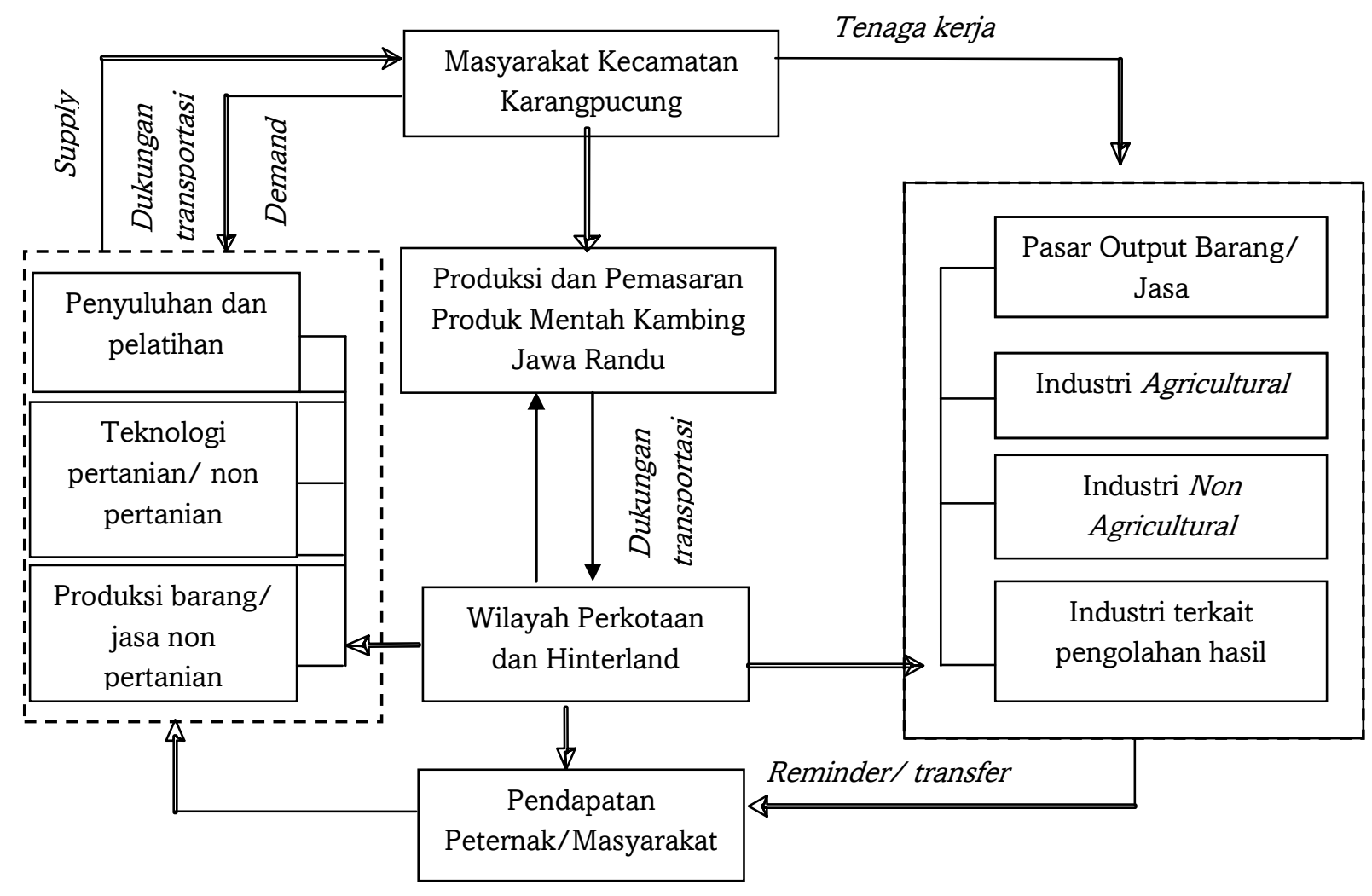
Gambar 2. Keterkaitan Rural-Urban dalam Lingkup Aktivitas Agribisnis Peternakan Kambing Jawa
Randu

\section{Analisis Backward-Forward Linkage}

a. Backward Linkage

- Kegiatan yang ditimbulkan Usaha Pembibitan

Berdasarkan analisis dari hasil wawancara dengan peternak, maka dapat digeneralisasikan kegiatan yang ditimbulkan oleh aktivitas usaha pembibitan adalah:

- Munculnya pembibitan dengan cara inseminasi buatan

- Penduduk yang mempunyai kambing berjumlah lebih dari 10 ekor menitipkan kambingnya ke tetangga/petani lain dengan sistem bagi hasil ataupun bagi anak.

- Munculnya kegiatan pemasaran kambing Jawa Randu yang melibatkan seluruh peternak kambing Kecamatan Karangpucung dengan pembeli berasal dari lokal, regional, bahkan luar regional Jawa Tengah

- Kegiatan yang Disebabkan oleh Usaha Pakan

Kegiatan peternakan kambing Jawa Randu tidak dapat terlepas dari usaha pengadaan pakan yang dilakukan oleh peternak. Kegiatan yang ditimbulkan oleh aktivitas usaha pengadaan pakan adalah sebagai berikut:

- Pengadaan hutan negara (Perhutani) yang dimanfaatkan untuk persediaan pakan ternak tanpa dikenakan biaya

- Kegiatan penanaman tanaman mendorong petani untuk membudidayakan pertanian pangan, seperti pertanian padi dan pertanian palawija. 
- Pengadaan kebun milik pribadi yang digunakan sebagai sumber persediaan pakan hijau selain hutan negara.

- Pembuatan fermentasi pakan hijau yang bisa digunakan untuk persediaan pakan pada musim kemarau di beberapa desa, sehingga peternak tidak perlu mengeluarkan biaya

- Pemanfaatan limbah tempe, tahu, dan gaber yang dimanfaatkan sebagai pakan komboran bagi kambing.

- Penyuluhan yang diadakan di setiap desa oleh PPL dari balai/dinas penyuluhan terkait

- Kegiatan yang ditimbulkan oleh Usaha Pembuatan Kandang dan Peralatan Penunjang Usaha peternak dalam pembuatan kandang dan pengadaan peralatan peternakan menimbulkan beberapa kegiatan yaitu:

- Pengadaan hutan negara (Perhutani) dan kebun pribadi yang menghasilkan kayu dan bambu yang digunakan sebagai bahan pembuatan kandang, sehingga peternak tidak perlu mengeluarkan biaya untuk membeli kayu/bambu.

- Kebutuhan peternak akan bahan-bahan lain selain kayu dan bambu, yaitu seperti paku, genteng, seng, dll menyebabkan banyaknya pembangunan toko-toko bahan material/bangunan. Kegiatan ini di satu sisi menguntungkan penjual, di sisi lain juga menguntungkan peternak, karena memudahkan peternak dalam mengakses bahan-bahan bangunan tersebut.

- Pembuatan dan perbaikan kandang ternak Kambing Jawa Randu memerlukan tenaga kerja, terutama jika kandang yang dibuat berukuran besar. Kegiatan ini dapat memberiikan pendapatan tambahan bagi tukang kayu.

\section{b. Forward Linkage}

- Kegiatan yang ditimbulkan Aktivitas Pengolahan Feses

Kegiatan yang ditimbulkan karena adanya aktivitas pengolahan kotoran kambing adalah sebagai berikut:

- Aktivitas pembuatan pupuk kompos yang terbuat dari kotoran dan urin kambing

- Aktivitas pemupukan pada lahan persawahan, yang mendukung ketahanan pangan Kecamatan Karangpucung

- Aktivitas pemupukan lahan perkebunan tanaman buah-buahan dan tanaman rambanan yang mendukung kegiatan hulu

- Aktivitas jual beli pupuk kandang

- Aktivitas penyuluhan mengenai pembuatan pupuk organik yang bernilai ekonomis

- Kegiatan yang ditimbulkan aktivitas pengolahan kulit

- Aktivitas jual beli kulit mentah basah yang dilakukan peternak dan pengepul yang bisa menambah pendapatan pengepul dan peternak

- Aktivitas pengolahan kulit menjadi kikil, namun masih dilakukan dalam skala kecil

- Kegiatan jual beli kulit mentah basah antara pengepul lokal dan pengepul regional

- Kegiatan industri pengeringan dan penyamakan kulit mentah basah di wilayah perkotaan, yang bisa menyerap tenaga kerja dari wilayah pedesaan Kecamatan Karangpucung.

- Kegiatan yang ditimbulkan aktivitas pemasaran kambing Jawa Randu

- Perdagangan tingkat lokal, regional, dan nasional yang meningkatkan pendapatan peternak

- Renovasi pasar kambing Jawa Randu

- Penyewaan mobil terbuka untuk memperlancar pengangkutan kambing ke pasar dan distribusi ke luar kota 
- Pembangunan dan perbaikan jalan desa baik secara swadaya maupun oleh pemerintah

\section{Analisis Penerapan Sistem Agribisnis Peternakan Kambing Jawa Randu dalam Kerangka Pengembangan Wilayah Kecamatan Karangpucung}

a. Terhadap Peningkatan Pendapatan

Berikut adalah tabel peningkatan pendaatan peternak jika dilakukan sistem agribisnis pada kegiatan peternakan Kambing Jawa Randu.

Tabel 1. Peningkatan Pendapatan Peternak Jika Dilakukan Agroindustri

\begin{tabular}{|c|c|}
\hline Tanpa Agroindustri & Jika Dilakukan Agroindustri \\
\hline \multirow{3}{*}{$\begin{array}{l}\text { Penjualan kambing dan pupuk } \\
\text { kandang } \\
=\text { Rp } 676.875,00 \text { per bulan }\end{array}$} & $\begin{array}{l}\text { Usaha pengolahan kulit } \rightarrow \text { kerupuk rambak } \\
=\mathrm{Rp} 3.525 .565,19 \text { per bulan }\end{array}$ \\
\hline & $\begin{array}{l}\text { Usaha susu murni kambing Jawa Randu } \\
=\text { Rp 6.623.342,10 per bulan }\end{array}$ \\
\hline & $\begin{array}{l}\text { Usaha rumah potong hewan kambing Jawa Randu } \\
\text { (usaha kelompok) } \\
=\text { Rp 88.692.774,17 per bulan }\end{array}$ \\
\hline
\end{tabular}

b. Terhadap Penyerapan Tenaga Kerja

Berdasarkan perhitungan yang telah dilakukan, jumlah tenaga kerja yang terserap dalam aktivitas agribisnis peternakan kambing Jawa Randu adalah sebanyak 6.945 orang dari total tenaga kerja dari sektor pertanian di Kecamatan Karangpucung yang berjumlah 35.659 yang terdiri atas pemilik tanah, penggarap, dan buruh tani (Monografi Kecamatan Karangpucung, 2011). Apabila betul-betul dikembangkan maka tenaga kerja produktif tidak perlu meninggalkan sektor pertanian menuju ke perkotaan, karena industri di wilayah sendiri sudah cukup menjanjikan.

c. Terhadap Penyediaan Bahan Pangan

Aktivitas peternakan kambing Jawa Randu terkait erat dengan kegiatan pertanian pangan, hortikultura dan perkebunan, serta peternakan lain. Berikut adalah skema hubungan peternakan kmbing Jawa Randu dengan penyediaan bahan pangan bagi masyarakat Karangpucung:

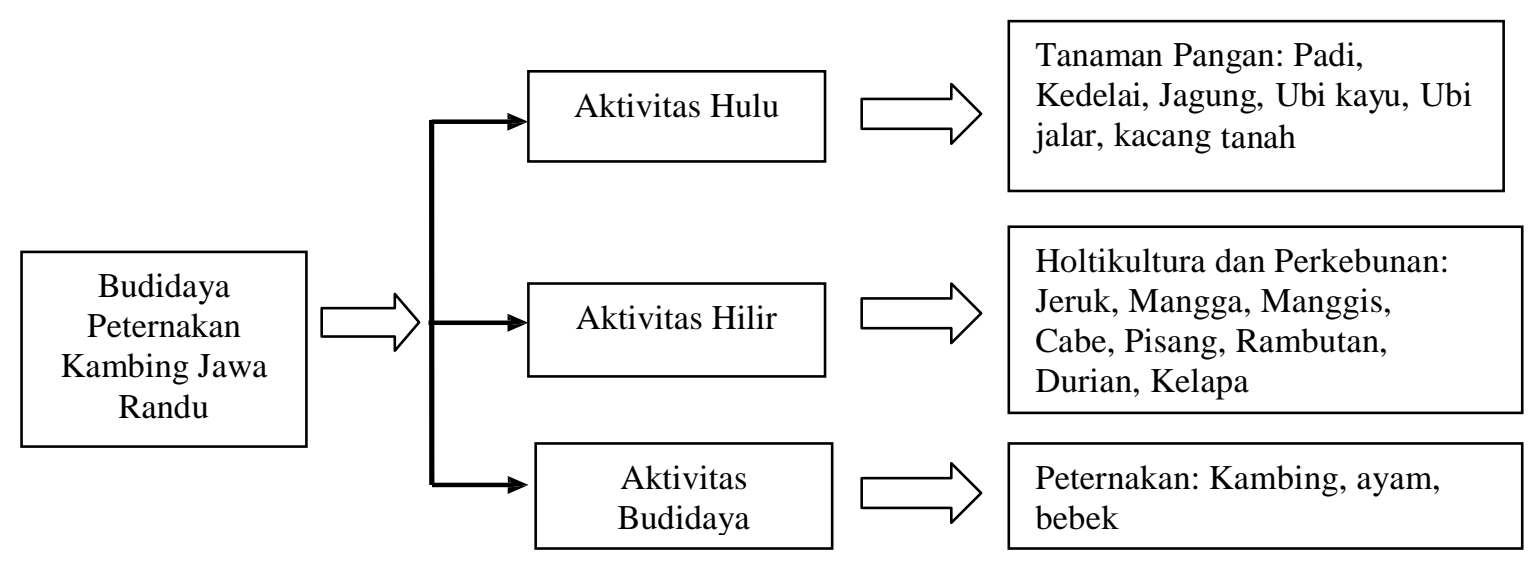

Gambar 3. Keterkaitan Aktivitas Peternakan Kambing Jawa Randu dengan Ketersediaan Bahan Pangan 
d. Terhadap Pengembangan Fisik Kecamatan Karangpucung

Untuk mendukung kegiatan agribisnis dan untuk membentuk kawasan agropolitan, maka diperlukan sarana yang mendukung dan menunjang kegiatan tersebut. Sarana yang dimaksud adalah seperti perbaikan dan penambahan luas pasar kambing Jawa Randu, pendirian toko pertanian dan obat-obatan hewan, pendirian balai pembibitan, penyuluhan dan pelatihan, serta industri sendiri. Berikut adalah peta persebaran sarana pendukung kegiatan agribinis jika diterapkan dalam aktivitas peternakan kambing Jawa Randu.

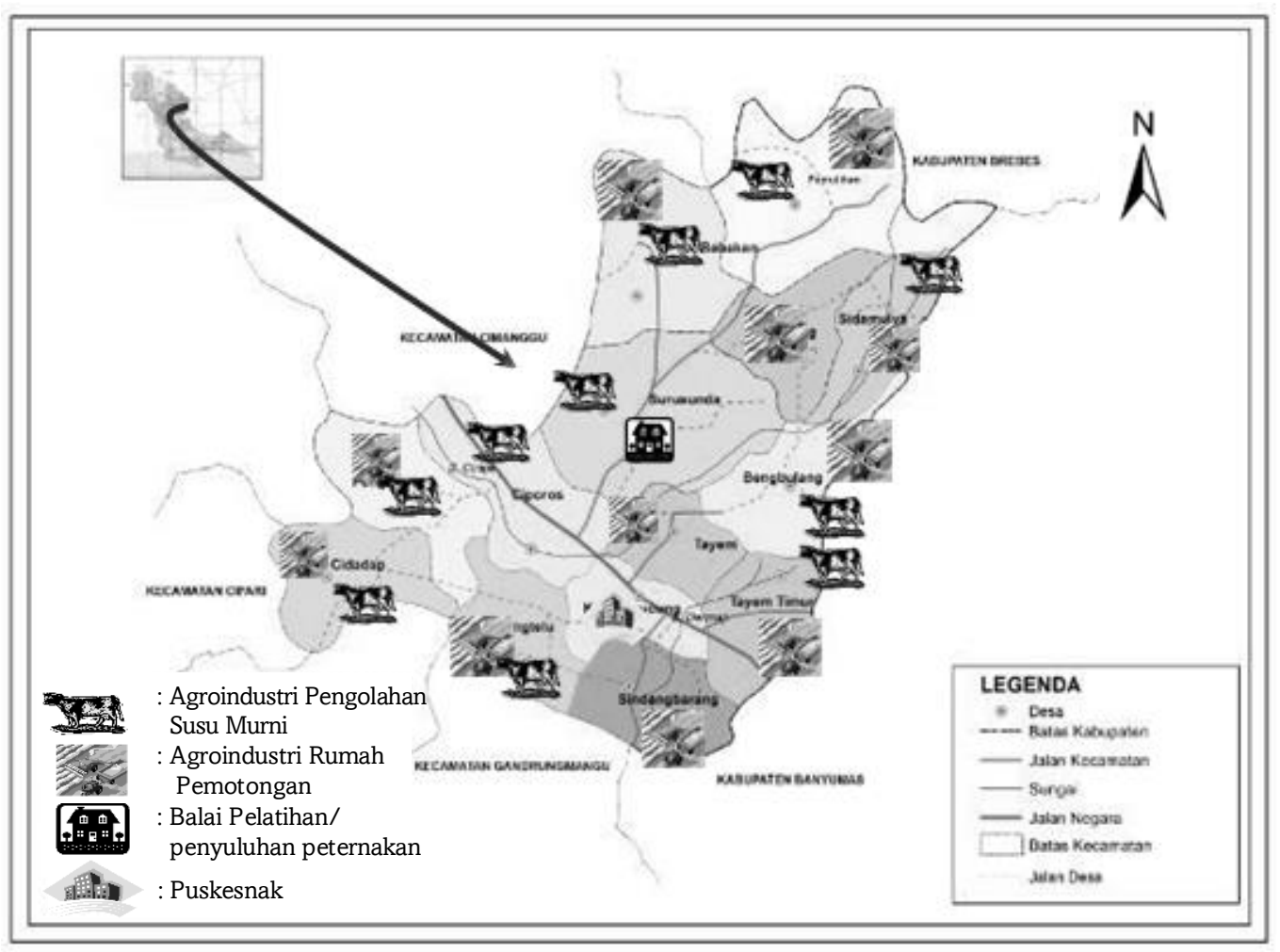

Gambar 4. Persebaran Sarana Jika Diterapkan Sistem Agribisnis Peternakan Kambing Jawa Randu

\section{Kesimpulan}

- Aktivitas peternakan kambing Karangpucung merupakan kegiatan usaha sambilan;

- Aktivitas peternakan kambing Karangpucung terdiri atas aktivitas hulu, budidaya yang sangat sederhana, hilir hanya berupa pengolahan pupuk, dan penunjang;

- Kegiatan peternakan kambing Karangpucung belum berorientasi pada bisnis;

- Aktivitas peternakan kambing Karangpucung telah menimbulkan keterkaitan kebelakang dan ke depan (backward forward linkage);

- Terdapat hubungan/keterkaitan antar wilayah internal dan rural-urban linkage;

- Aktivitas peternakan kambing Karangpucung masih terkonsentrasi pada kegiatan on farm, belum ada variasi usaha di subsistem hilir;

- Peternak hanya memperoleh Rp 676.875,-- per bulan, namun jika dilakukan agroindustri berupa pengolahan kulit, susu, dan daging akan meningkatkan pendapatan bagi peternak/pelaku usaha; 
- Bila diterapkan sistem agribisnis peternakan kambing Karangpucung, maka akan berpengaruh terhadap peningkatan pendapatan, penyerapan tenaga kerja, dan penyediaan bahan pangan.

\section{Rekomendasi}

- Untuk Pemerintah Daerah:

- Membentuk institusi/lembaga yang fokus mencermati pengembangan peternakan kambing Karangpucung;

- Menyusun kebijakan berupa sertifikasi kambing Jawa Randu ras Karangpucung menjadi "Kambing Karangpucung";

- Meningkatkan pembangunan infrastruktur;

- Meningkatkan akses masyarakat peternak terhadap pinjaman modal, yaitu dengan kredit mikro dengan membentuk koperasi;

- Mengembangkan peternakan kambing Karangpucung sebagai pendorong Local Economic Development.

- Untuk Masyarakat Peternak:

- Sebaiknya mulai memanfaatkan teknologi informasi untuk meningkatkan pengetahuan tentang budidaya peternakan kambing;

- Memanfaatkan limbah pertanian untuk difermentasi menjadi pakan;

- Peternak mengubah pola peternakan kepada kegiatan yang lebih berorientasi bisnis yaitu dengan mengolah kulit, daging, dan susu dari Kambing Karangpucung;

- Membentuk kelompok peternakan, agar proses transformasi budidaya peternakan dari tradisional menjadi berorientasi agribisnis akan lebih mudah dilakukan.

- Untuk Studi Lanjutan:

- Mengkaji strategi agar potensi pertanian dan perkebunan, sumber daya alam, dan sumber daya manusia yang ada di Karangpucung dapat terintegrasi dengan penerapan sistem agribisnis peternakan Kambing Karangpucung, sehingga Karangpucung mampu menjadi kawasan agropolitan.

\section{Daftar Pustaka}

Arifin, Bustanul. 2004. Analisis Ekonomi Pertanian Indonesia. Jakarta: Penerbit Buku Kompas

Austin, James E. 1992. Agroindustrial Project Analyis Critical Design Factors. EDI Series in Economic Development. Maryland: The John Hopkins University Press

Database Kelompok Tani Kecamatan Karangpucung Tahun 2011. BP2KP Kecamatan Karangpucung

Fatah, Luthfi. 2006. Dinamika Pembangunan Pertanian dan Pedesaan. Banjarbaru: Jurusan Sosial Ekonomi Fakultas Pertanian Universitas Lambung Mangkurat dengan Pustaka Benua

Firdaus, Muhammad. 2008. Manajemen Agribisnis. Jakarta: Bumi Aksara

Gittinger, J. Price. 1986. Analisa Proyek - Proyek Pertanian. Edisi Kedua. Universitas Indonesia: Jakarta

Hetherington, Lois. 1987. All About Goats. Farming Press LTD. British Library Cataloguing in Publication Data.

Kecamatan Karangpucung Dalam Angka Tahun 2010. Badan Pusat Statistik Kabupaten Cilacap

Lincoln, Arsyad. 2004. Ekonomi Pembangunan. Bagian Penerbitan STIE Ilmu Ekonomi YKPN

Mahaputra, Ketut dkk. 2006. Analisis Usaha Penggemukan Sapi Bali dan Pengolahan Hasil Limbah Sebagai Pupuk Organik Padat dan Cair. Bali: Balai Pengkajian Teknologi Pertanian Bali

Mappigau, Palmarudi dan A. Sawe Ri Esso. 2011. "Analisis Strategi Pemasaran Telur Pada Peternakan Ayam Ras Skala Besar di Kabupaten Sidrap”. Jurnal Agribisnis, Vol. X (3),September, hal. 14-37 
Marsono. 2011. Karangpucung Integrated Sheep Ranch In Cilacap Regency. KPPT Kabupaten Cilacap

Monografi Kecamatan Karangpucung Tahun 2010

Mubyarto. 1995. Pengantar Ekonomi Pertanian. Jakarta: Lembaga Penelitian, Pendidikan, dan Penerangan Ekonomi dan Sosial

Narullah, Ahmad dan Benni Setiawan. 2011. "Membangun Desa Mandiri Pangan”. Jurnal Nasional, Oktober, 2011.

Nugraheni. 2010. “Pengembangan Pola Agribisnis Ternak Kambing Etawa Dengan Sistem Pertanian Terintegrasi di Kecamatan Kaligesing.” Tugas Akhir tidak diterbitkan, Program Studi Perencanaan Wilayah dan Kota, Fakultas Teknik Universitas Diponegoro, Semarang.

Oktafiyani, Roch Ika. 2009. “ Analisis Kelayakan Usaha Pembuatan Kerupuk Rambak Kulit Sapi dan Kulit Kerbau (Studi Kasus: Usaha Pembuatan Kerupuk Rambak di Kecamatan Pegandon Kabupaten Kendal, Jawa Tengah)”. Skripsi tidak diterbitkan. Departemen Agribisnis, Fakultas Ekonomi dan Manajemen, Institut Pertanian Bogor.

Penyusunan Model Pengembangan Agribisnis Pakan Ternak Untuk Mendukung Program Sapi Perah. Melalui Koperasi. 2006. Jurnal Pengkajian Koperasi dan UKM Nomor 2 Tahun I-2006

Putria, Rona. 2008. “Analisis Kelayakan Usaha Pengembangan Pembibitan (Breeding)Sapi Potong Pada Pt Lembu Jantan Perkas (Ljp),Serang, Propinsi Banten.” Tugas Akhir tidak diterbitkan Program Sarjana Ekstensi Manajemen Agribisnis, Fakultas Pertanian, Institut Pertanian Bogor, Bogor.

Ricketts, Cliff \& Kristina. 2009. Agribusiness: Fundamentals and Aplications, 2nd Edition. USA: Delmar

Rustiadi, Ernan dan Sugimin Pranoto. 2002. Agropolitan Membangun Ekonomi Perdesaan. Bogor: Crestpent Press

Sabaroh, Catur. 2000. “Manajeman Usaha Ternak Kambing PE di KTT Sidomaju II Desa Pandanrejo Kecamatan Kaligesing Kabupaten Purworejo (Potensi dan Komposisi Hijauan Pakan)”. Tugas Akhir tidak diterbitkan. Program Studi D III Manajemen Usaha Peternakan, Fakultas Peternakan Universitas Diponegoro, Semarang.

Santosa, Purbayu Budi. 2005. "Pembangunan Sektor Pertanian Melalui Pola Agribisnis Menuju Ketangguhan Perekonomian Indonesia”. Dialogue JIAKP, Vol. 2 No. , hal. 674-685

Saragih, Bungaran. 2000. Kumpulan Pemikiran Agribisnis Berbasis Peternakan. Pusat Studi Pembangunan, Lembaga Penelitian, Institut Pertanian Bogor 2000. "Agribisnis Sebagai Landasan Pembangunan Ekonomi Indonesia Dalam Era Milenium Baru”. Jurnal Studi Pembangunan, Kemasyarakatan \&Lingkungan, Vol 2, no.1/Februari, hal 1-9.

Soekartawi. 2007. "e-Agribisnis: Teori dan Aplikasinya”. Makalah disampaikan pada Seminar Nasional Aplikasi Teknologi Informasi, Yogyakarta, 16 Juni 2007

Sosrowijojo, Samuel. 1998. Ternak Potong dan Kerja. Jakarta: CV Yasaguna

Sudradjat D, Sofyan dan Rachmat Pambudy. 2000. Menjelang Dua Abad Sejarah Peternakan dan Kesehatan Hewan Indonesa: Peduli Peternak Rakyat. Jakarta: Yayasan Agrindo

Sugiyono. 2010. Metode Penelitian Kuantitatif dan Kualitatif dan $R \& D$. Bandung: Penerbit Alfabeta

Suparta, Nyoman. 2002. Penyuluhan Sistem Agribisnis Suatu Pendekatan Holistik. Bali: PS. Sosek dan Agribisnis, Fakultas Peternakan Universitas Udayana

Tarigan, A. 2003. Rural Urban Economic Linkages. Konsep dan Urgensinya Dalam Memperkuat Pembangunan Desa.

Winarso, Bambang. Prospek dan Kendala Pengembangan Agribisnis Ternak Kambing dan Domba di Indonesia. Bogor: Pusat Analisis Sosial Ekonomi dan Kebijakan Pertanian 
156 Penerapan Sistem Agribisnis Peternakan Kambing Jawa Randu dalam Kerangka Pengembangan Wilayah

JURNAL WILAYAH DAN LINGKUNGAN, 1 (2), 141-156 